\title{
Reproduction of Calanus glacialis in the Lurefjord (western Norway): indication for temperature-induced female dormancy
}

\author{
Barbara Niehoff ${ }^{*}$, Hans-Jürgen Hirche
}

Alfred Wegener Institute for Polar and Marine Research, Columbusstr 1, 27568 Bremerhaven, Germany

\begin{abstract}
The reproductive activity of Calanus glacialis was studied during the winter-spring transition 1996 in the Lurefjord, western Norway, focussing on the impact of phytoplankton development and temperature. Depth-stratified samples were taken at weekly intervals to determine female abundance, vertical distribution and gonad development stage. Single live females were incubated to measure in situ egg production rate, clutch size and spawning frequency. These field observations were combined with feeding and starvation experiments to study the importance of food supply in greater detail. The depth distribution of the females changed during the investigation period. On February 28, most females were located between the surface and $100 \mathrm{~m}$. During March, the majority of the females inhabited the upper $50 \mathrm{~m}$, and by mid-April, most females had migrated to depths below $100 \mathrm{~m}$. The reproductive activity of $C$. glacialis was uncoupled to the phytoplankton bloom. Females were already mature at the beginning of March and egg production began. Maximum reproduction was recorded on March 28 before the beginning of the spring bloom; thereafter, gonad maturity and egg production rates declined rapidly before the end of the bloom, and by April 11 the majority of females had migrated to depths $>100 \mathrm{~m}$. No faecal pellets were produced when these females were offered food, and gonads became equally depleted in females starving or feeding for $5 \mathrm{~d}$, indicating a deep physiological change such as dormancy. The descent of the females to lower depths and the arrest of their reproductive activity were apparently related to a temperature increase in the surface layer, similar to earlier observations in the White Sea.
\end{abstract}

KEY WORDS: Calanus glacialis · Reproduction · Gonad development · Egg production · Seasonal cycle

Resale or republication not permitted without written consent of the publisher

\section{INTRODUCTION}

Calanus species are the dominant calanoid copepods in the North Atlantic, each species being associated with certain water masses: $C$. helgolandicus is found in the southern parts of the North Atlantic and in the North Sea; C. finmarchicus is associated with Atlantic water; C. glacialis usually inhabits Arctic shelf seas; while the main distribution area of $C$. hyperboreus is the Greenland Sea, the Labrador Sea and the Arctic Ocean (e.g. Grainger 1963, Hopkins 1969, Jaschnov 1970, Conover 1988, Hirche \& Mumm 1992, Hirche 1997). To understand the factors controlling reproduction and population dynamics of these species, it is essential to study physical and biological processes in the marine environment in relation to their life-history traits. In this respect, frequent assessment of stage composition, vertical distribution and reproductive rates is important. Such studies are, however, rare as they require large logistical efforts. The most complete data available on reproduction are for $C$. finmarchicus, the target species of international projects such as the EU Projects ICOS (Investigation of Calanus finmarchicus migrations between oceanic and shelf seas off north-west Europe) and TASC (TransAtlantic Studies of Calanus finmarchicus), or the US GLOBEC Georges Bank Program. Only a few time series were conducted in the open sea (e.g. Weathership Stn M: Irigoien et al. 
1998, Niehoff et al. 1999, Hirche et al. 2001; Georges Bank: Durbin et al. 2000, Campbell et al. 2001). The majority of studies were close to the coast such as in the Gulf of St. Lawrence, Canada, (Plourde \& Runge 1993), Disko Bay, Greenland, (Niehoff et al. 2002) and some Norwegian fjords (e.g. Marshall \& Orr 1955, Diel $\&$ Tande 1992, Niehoff 2000). These studies emphasise the coupling of phytoplankton development and reproduction in spring. As the onset of phytoplankton blooms depends on the light regime and stratification, strong regional and latitudinal gradients are expected in the reproductive activity of $C$. finmarchicus. Studies in the Norwegian Sea and around Iceland showed early reproduction in coastal currents due to early stratification of the water column and corresponding phytoplankton blooms (Gislason \& Astthorsson 1996, Gaard 2000, Niehoff \& Hirche 2000). To investigate the latitudinal gradient, we chose the Lurefjord, western Norway (approx. $60^{\circ} \mathrm{N}$ ), as a southern location. To our surprise, however, not only the size but also the colour of live specimens indicated that the majority were $C$. glacialis rather than C. finmarchicus. This impression was later confirmed by genetic studies by Bucklin et al. (2000) and morphological studies by E. Bagøien (unpubl. data). As seasonal data on the reproduction of C. glacialis were scarce, we studied the reproductive activity of C. glacialis in a very southerly distribution area and compared it with the northern populations (East Greenland: Hirche \& Kwasniewski 1997; West Greenland: Niehoff et al. 2002; White Sea: Kosobokova 1999). We focused on the impact of phytoplankton development and temperature on gonad maturity and egg production rates. In addition, our field observations were combined with feeding and starvation experiments to study the importance of food supply in greater detail.

\section{MATERIALS AND METHODS}

Hydrography and chlorophyll a. At each station, salinity and temperature were measured by a Seabird CTD. To determine the chlorophyll a (chl a) concentration, water samples were taken with 101 Niskin bottles at $5 \mathrm{~m}$ intervals from a depth of $45 \mathrm{~m}$ to the surface. These measurements were conducted by D. Aksnes and his group (High Technology Centre Bergen, Norway). The sampling procedure and results are described in detail by Bagøien et al. (2001) and Eiane et al. (2002).

Sampling. Zooplankton was collected at a station in the Lurefjord (430 $\mathrm{m}$ depth), western Norway $\left(60^{\circ} 41.00^{\prime} \mathrm{N}, 05^{\circ} 10.50^{\prime} \mathrm{E}\right)$, at weekly to biweekly intervals with RV 'Hans Brattstrøm' (University of Bergen, Norway) from February 28 to June 14, 1996. Depth- stratified samples $(430,300,200,100,50,0 \mathrm{~m})$ were taken during the day (10:00 to $12: 00 \mathrm{~h}$ ) with a multi-net (Hydrobios, mesh size $180 \mu \mathrm{m}$, net opening $0.25 \mathrm{~m}^{2}$ ) and preserved in $4 \%$ formalin buffered with borax. On March 28, the multi-net did not work due to technical problems, and Nansen net samples (mesh size $300 \mu \mathrm{m}$, $70 \mathrm{~cm}$ diameter, $0.38 \mathrm{~m}^{2}$ ) were taken from 50 and $400 \mathrm{~m}$ to the surface. The abundance of Calanus females and their gonad maturity stage were determined for all samples.

Species identification. According to genetic analysis, the 3 species Calanus glacialis, C. finmarchicus and $C$. helgolandicus co-occur in the Lurefjord, with C. glacialis comprising $69 \%$ of all Calanus species (Bagøien 1999, Bucklin et al. 2000). Live C. glacialis females can be distinguished from the other Calanus species in the fjord by their swimming patterns and pigmentation (Smith \& Schnack-Schiel 1990). Furthermore, the species differ in size, with C. glacialis being the largest (Smith \& Schnack-Schiel 1990, Hirche et al. 1994). For the experiments, we picked the largest individuals, and thus the majority of these females were probably C. glacialis.

In the preserved samples, species were not distinguished, as the morphological characteristics of the preserved individuals were inconclusive. Prosome length was, however, measured from the tip of the cephalosome to the distal lateral end of the last thoracic segment, using a video-image digitising system (VIDS III, AT Tektron) with a resolution of $25 \mu \mathrm{m}$. Female prosome length averaged $2937 \mu \mathrm{m}$ and did not change with time (Fig. 1A) or with depth. The length frequency was normally distributed, with 1 single peak confirming the dominance of C. glacialis (Fig. 1B). For comparison, C. finmarchicus females from Weathership $\mathrm{M}\left(66^{\circ} \mathrm{N}, 2^{\circ} \mathrm{E}\right)$ collected in 1997 at the same time of year are smaller at very similar water temperatures (Niehoff et al. 1999, Fig. 1C). Compared to C. glacialis females in Arctic seas (e.g. East Greenland Shelf: 3.2 to $4.6 \mathrm{~mm}$, mean $3.85 \mathrm{~mm}$; White Sea: 3.6 to $4.5 \mathrm{~mm}$, mean $4.1 \mathrm{~mm}$ ), females from the Lurefjord were considerably smaller; however, Smith \& Schnack-Schiel (1990) also reported considerably smaller individuals (2.6 to $4.0 \mathrm{~mm}$, their Fig. 10.2) from the Greenland Sea, where Arctic and Atlantic waters mix.

Gonad maturity and morphology. Gonad maturity was established from preserved females, which were first stained with borax carmine, then dehydrated in standard ethanol series and finally stored in glycerine. The gonad development stage (GS) was classified in accordance with the classification scheme of Niehoff \& Hirche (1996). GS1, GS2 and GS3 describe females of increasing maturity characterised by an increase in oocyte numbers and development stage in anterior and posterior diverticula of the gonads. In mature gonads 

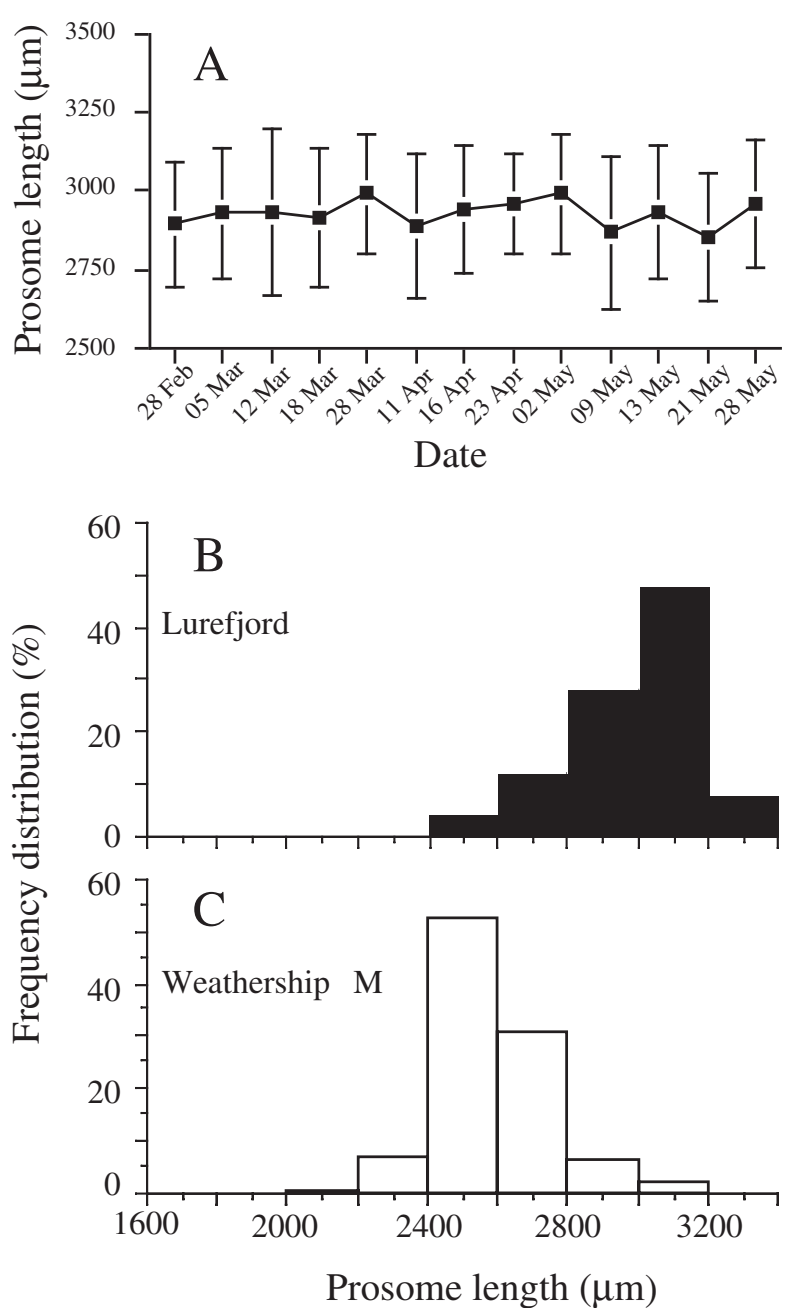

Fig. 1. Calanus spp. Female prosome length. (A,B) Calanus spp. in the Lurefjord, western Norway, from February to June 1996. (A) Mean length $(n=50)$, error bars represent \pm SD. (B) Length frequency distribution. (C) C. finmarchicus length frequency distribution at Weathership M, Norwegian Sea, March to May 1996

(GS4), 1 or 2 ventral layers of oocytes undergo final maturation. Females carrying degenerating oocytes in the diverticula or females with no visible oocytes in the ovary or the diverticula are characterised as 'degenerating' (D).

Egg production experiments. The in situ egg production rate, clutch size and proportion of spawning females were determined weekly from February 28 to June 16, 1996. For collection of live females for egg production experiments, vertical Nansen net hauls were conducted from 200 m (February, March) or from $400 \mathrm{~m}$ (April to June) to the surface. Females from the Nansen net samples were sorted on board within $1 \mathrm{~h}$ of capture. Fifty single females were immediately placed into $200 \mathrm{ml}$ Plexiglas cylinders with net false bottoms to separate females and eggs. These cylinders were suspended in beakers. One half of the females was kept in pre-filtered seawater $(0.45 \mu \mathrm{m})$, and the other half in filtered seawater inoculated with the diatom Thalassiosira weissflogii at concentrations $>30 \mu \mathrm{g} \mathrm{chl} \mathrm{a} \mathrm{l}^{-1}$. The beakers were transported in cooling boxes, within $2 \mathrm{~h}$, to the cold room at the High Technology Centre, Bergen, where they were kept at ambient sea surface temperature. After 24 h, eggs were counted. As laboratory conditions do not usually affect egg production during the first $24 \mathrm{~h}$ after capture, we consider these rates to be in situ egg production rates (Runge \& Roff 2000). To study the influence of feeding and starvation during the winter-spring transition, we continued to incubate the females for the following $5 \mathrm{~d}_{i}$ half of them in filtered seawater, the other half feeding on $T$. weissflogii. Eggs were counted daily and females were placed in fresh solutions. At the end of the $5 \mathrm{~d}$ incubation period, females were preserved for gonad analysis.

\section{RESULTS}

\section{Hydrography and chlorophyll a}

Eiane et al. (2002) described the seasonal cycle of temperature and chl $a$ in the Lurefjord. The mean temperature in the upper $50 \mathrm{~m}$ is presented in Fig. 2A and vertical temperature profiles are shown in Fig. 3. The upper $100 \mathrm{~m}$ were cooler than the rest of the water column until the end of March, when surface temperatures increased. In contrast, the deeper layer became colder after mid-March, but from May onwards, temperatures in the deepest layer increased again. Chl a levels were below $1 \mu \mathrm{g} \mathrm{l}^{-1}$ until the beginning of April (Table 1, Fig. 2A). Elevated concentrations of $>1 \mu \mathrm{g} \mathrm{l^{-1 }}$ were found between 10 and $30 \mathrm{~m}$ from mid-April to the end of May.

\section{Female abundance and distribution}

Calanus females were found throughout the investigation period from February 28 to June 16, 1996. Abundance was highest at the end of February at 3340 females $\mathrm{m}^{-2}$; during March and the beginning of April, it decreased to 280 females $\mathrm{m}^{-2}$. From April 16 until the end of sampling, female abundance varied between 1200 and 2500 ind. $\mathrm{m}^{-2}$.

The depth distribution of the Calanus females changed considerably during the investigation period and seemed to follow low water temperatures (Fig. 3). On February 28, most females were located between 0 and $50 \mathrm{~m}(50 \%)$, and more than $30 \%$ were found be- 

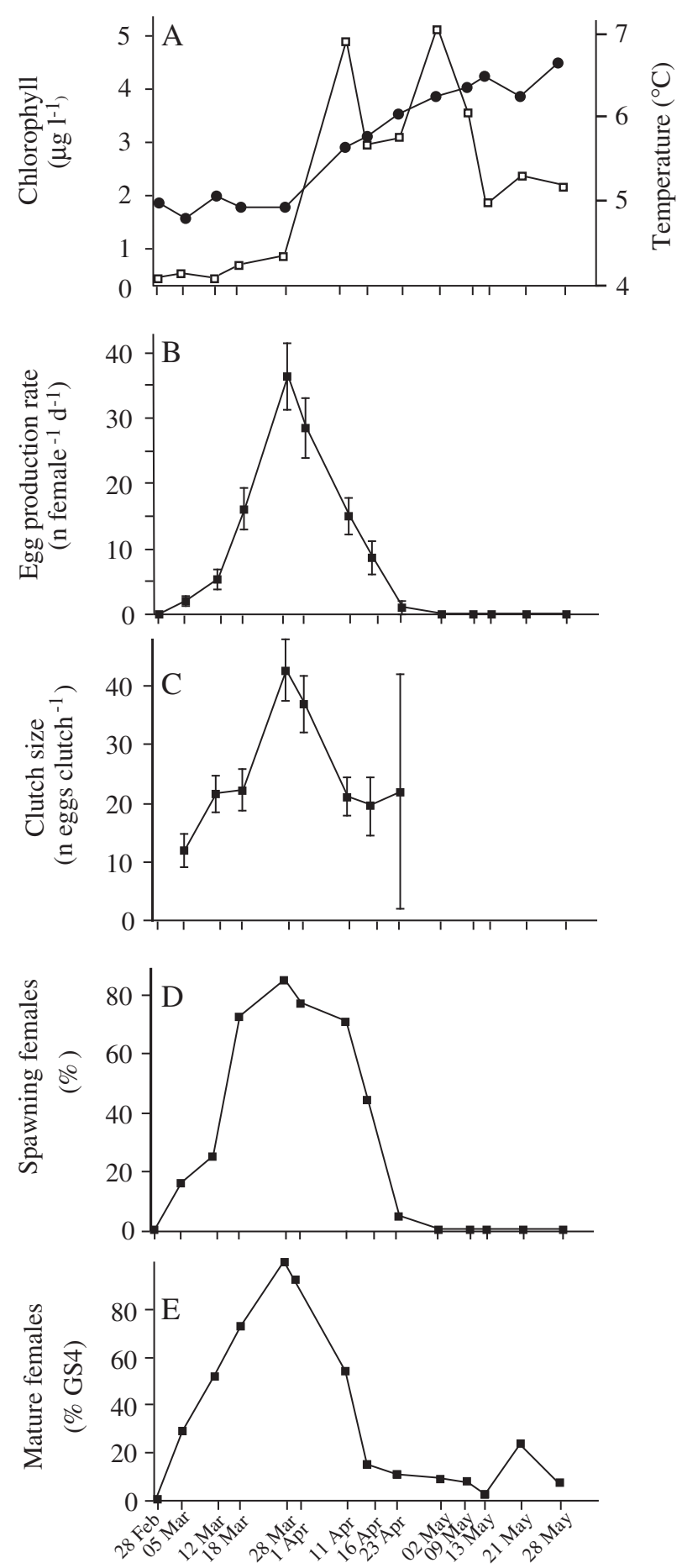

Fig. 2. Calanus glacialis. In situ reproductive activity in relation to (A) chlorophyll a concentration ( $\square$ ) and temperature $(\bullet)$ in the Lurefjord. (B) Mean egg production rate. (C) Mean clutch size. Error bars represent \pm SE. (D) Proportion of spawning females as percentage of females spawning within the first $24 \mathrm{~h}$ after capture. (E) Proportion of mature Calanus females as percentage of females in gonad development stage 4 (GS4) estimated from preserved samples. Note that in preserved samples, Calanus species were not distinguished, and hence all are included
Table 1. Chlorophyll a. Integrated ( 0 to $45 \mathrm{~m}$; $\mathrm{mg} \mathrm{m}^{-2}$ ), maximum and minimum ( $\mathrm{g} \mathrm{l}^{-2}$ ) concentrations in the Lurefjord, western Norway, in 1996

\begin{tabular}{|lrcc|}
\hline Date & Integrated & Minimum & Maximum \\
\hline $14 \mathrm{Feb}$ & 13.4 & 0.127 & 0.426 \\
$28 \mathrm{Feb}$ & 8.7 & 0.065 & 0.321 \\
$3 \mathrm{Mar}$ & 12.7 & 0.074 & 0.438 \\
$12 \mathrm{Mar}$ & 9.0 & 0.041 & 0.335 \\
$18 \mathrm{Mar}$ & 16.6 & 0.078 & 0.873 \\
$28 \mathrm{Mar}$ & 25.7 & 0.146 & 1.048 \\
$11 \mathrm{Apr}$ & 184.8 & 0.770 & 11.290 \\
$16 \mathrm{Apr}$ & 102.2 & 0.297 & 4.736 \\
$23 \mathrm{Apr}$ & 107.8 & 0.330 & 9.951 \\
$2 \mathrm{May}$ & 126.0 & 0.378 & 8.731 \\
$9 \mathrm{May}$ & 147.5 & 0.512 & 8.133 \\
$13 \mathrm{May}$ & 68.5 & 0.033 & 7.176 \\
$21 \mathrm{May}$ & 93.0 & 0.105 & 12.295 \\
$28 \mathrm{May}$ & 90.4 & 0.311 & 4.712 \\
\hline
\end{tabular}

tween 50 and $100 \mathrm{~m}$. During the whole of March, the majority of the females $(>50 \%$ ) inhabited the upper $50 \mathrm{~m}$, where temperatures were lowest. However, by mid-April, surface temperatures had increased and most females had migrated to depths below $100 \mathrm{~m}$. Only a small portion $(<20 \%)$ were found in the surface water during sampling in May and June. With the increase in temperature below $250 \mathrm{~m}$ (Fig. 3A), females seemed to shift upward to the cooler intermediate layer.

\section{Gonad maturation and reproduction}

At the end of February, most Calanus females were immature (GS1, Fig. 4). Over $3 \mathrm{wk}$, the proportion of advanced (GS2 and GS3) and mature (GS4) gonads increased. From the end of March until April 11, most females were mature. In mid-April, within only $5 \mathrm{~d}$ (April 11 to 16), the proportion of females with gonads containing degenerating oocytes (D) increased from 24 to $83 \%$. This might indicate that females stopped feeding as females incubated in filtered seawater without food showed a similar response after $5 \mathrm{~d}$ (compare section 'Feeding experiments' below). The proportion of females with degenerating oocytes remained generally high until the end of the investigation period. GS3 and GS4 were not found in considerable proportions (23\% GS3, $25 \%$ GS4) until the end of May. As females for gonad studies were not sorted live, and consequently species were not distinguished, it is very likely that these females were $C$. finmarchicus or C. helgolandicus.

The depth distribution of the gonad development stages showed that mature females were concentrated in the upper $50 \mathrm{~m}$ water layer. Mature females were only found throughout the water column during the 


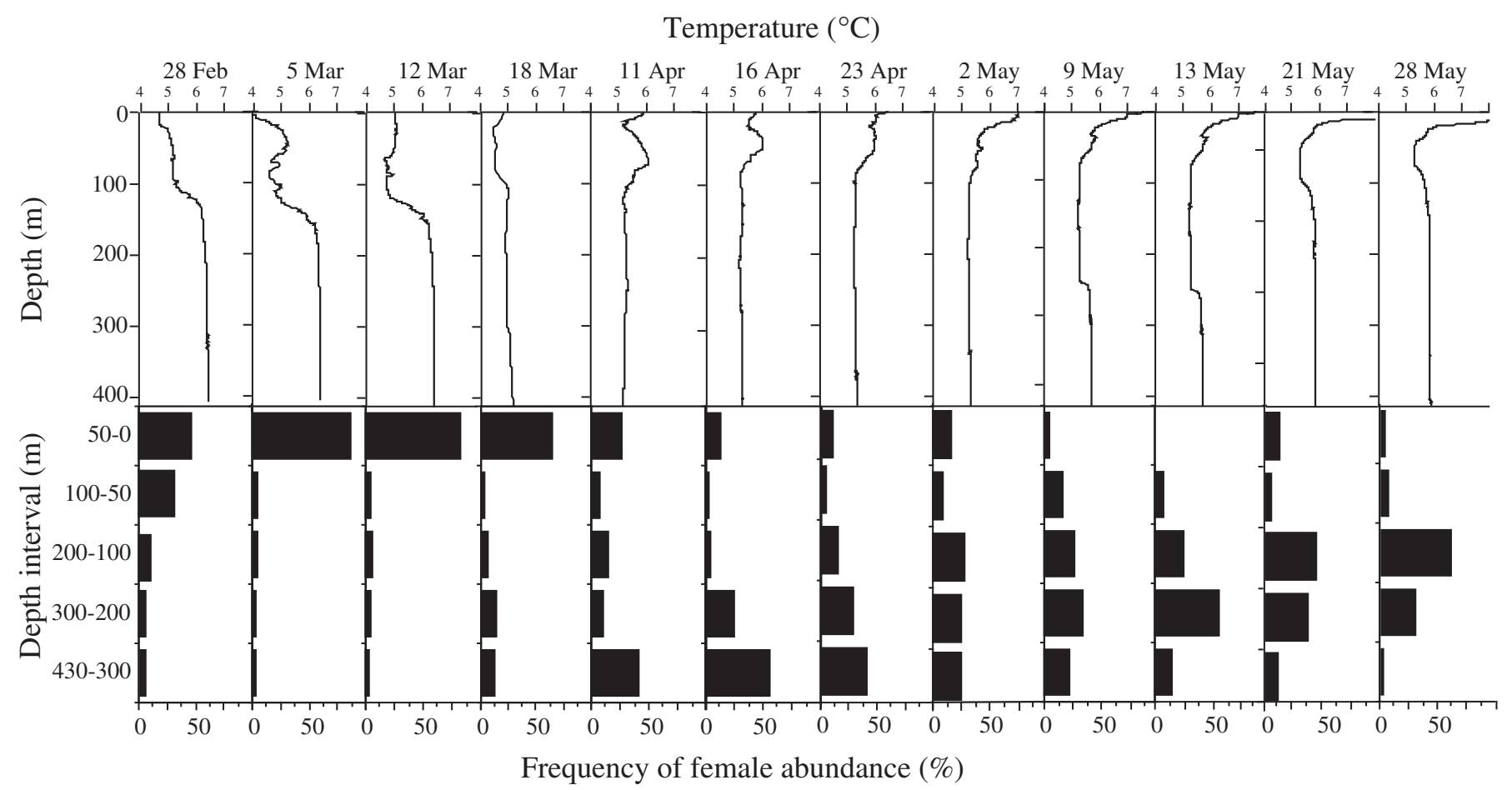

Fig. 3. Calanus spp. Vertical temperature profiles and depth distribution of females in the Lurefjord from February to May 1996

main reproductive period in March and April. In all other months, either immature females (February/ March) or females with degenerating gonads (April, May and June) dominated at depths below $50 \mathrm{~m}$.

\section{Reproductive activity in relation to chlorophyll a concentration}

The reproductive activity, i.e. gonad maturation and egg production rate as a function of spawning frequency and clutch size, did not show a significant correlation to the phytoplankton availability in the fjord (Fig. 2, ANOVA $\mathrm{p}>0.5, \mathrm{r}^{2}=0.004,0.008$ and 0.026). At the beginning of sampling on February 28, the chl a concentration was $0.25 \mu^{-1}$ (Fig. 2A). At that time, no mature females were found and egg production was zero (Fig. 2B), indicating that the reproductive period of Calanus glacialis had not yet started in the Lurefjord. Although the chl a concentration remained low $\left(<0.5 \mu \mathrm{g} \mathrm{l}^{-1}\right)$ until the end of March, the proportion of mature females increased to its maximum on March 28 (92\%) as did the egg production rate (36 eggs female ${ }^{-1}$ $\mathrm{d}^{-1}$ ). High egg production rates were due to both large clutches (up to 42 eggs) and high proportions of spawning females (Fig. 2C,D). After March 28, egg production decreased dramatically and it ceased by the beginning of May, despite the high chl a concentration $\left(>3 \mu \mathrm{g} \mathrm{l}^{-1}\right)$.

\section{Feeding experiments}

Feeding experiments were conducted after each cruise. Of the 10 experiments, 5 are presented here in detail (Fig. 5) and represent typical examples demonstrating the influence of feeding and starvation on

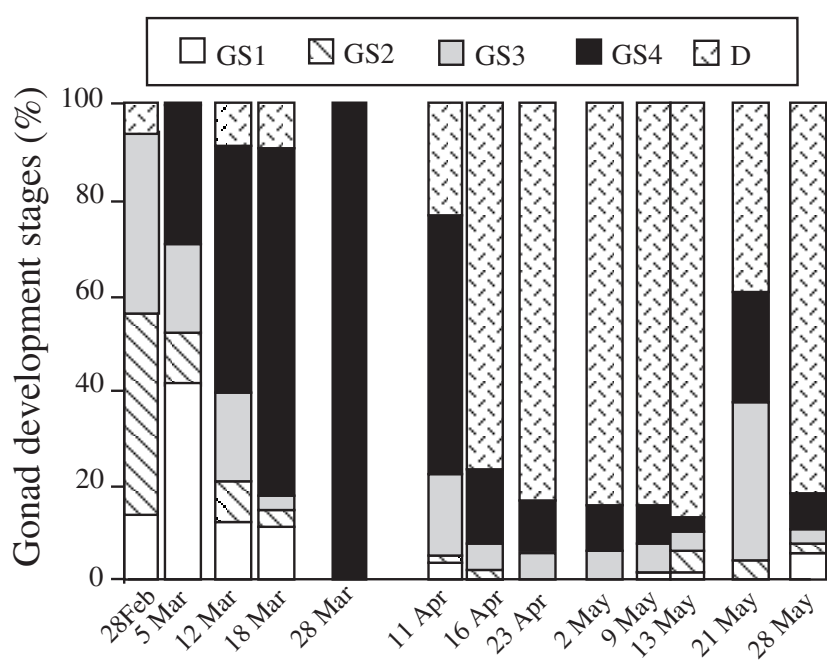

Fig. 4 Calanus spp. Female gonad development in the Lurefjord from February 28 to May 26, 1996. Gonad development stages (GS) were determined from preserved samples and are presented as percent of females in GS1 to 4 and D (females carrying degenerating oocytes). Fifty females were examined for each GS analysis 
reproduction in relation to in situ conditions. The remainder of the experiments show a similar pattern to those presented here. The first experiment was set up on February 28, when most females in the water column were still in immature (GS1) or advanced (GS2 and 3) gonad maturation stages (Fig. 5). Within $5 \mathrm{~d}$, $83 \%$ of the feeding females reached maturity, and low egg production was observed at Day 3. In contrast, the gonad stage composition of starving females did not change.

By March 12, the majority of the females in the fjord were mature but egg production was still low at approx. 5 eggs female ${ }^{-1} \mathrm{~d}^{-1}$. During the experiment, feeding resulted in an increase in egg production, while gonad maturity did not change (Fig. 5). The increase was due to a rise in both the proportion of spawning females from 20 to $50 \%$ and the clutch size from 25 to 32 eggs clutch $^{-1}$. Under starvation condi-
A
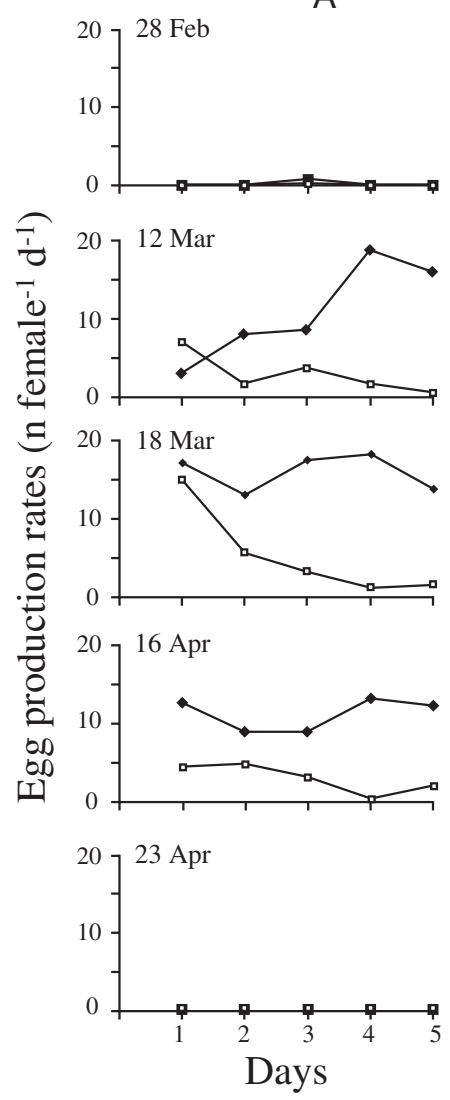
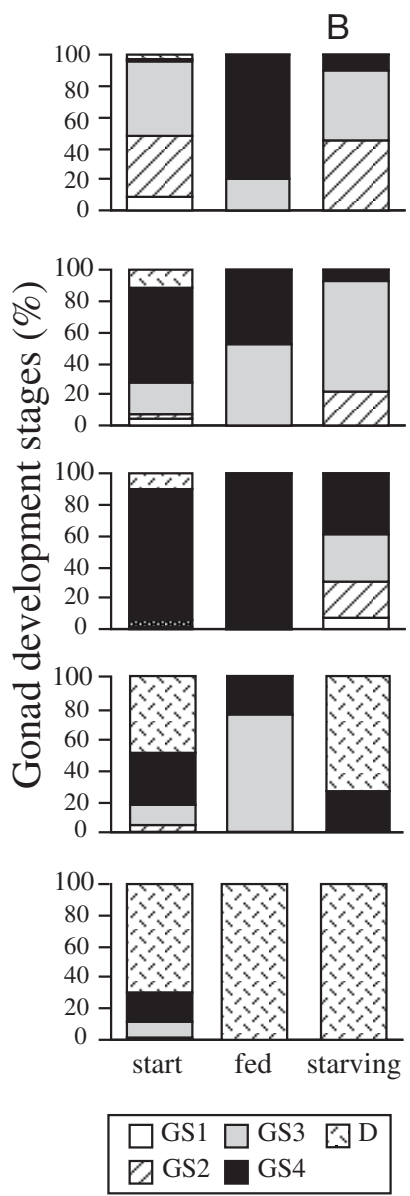

Fig. 5. Calanus glacialis. Egg production rates and gonad development stages (GS) of (A) feeding and (B) starving females (February 28 to April 23). Squares in (A) represent means of 25 females: $\mathbf{n}$, fed; $\square$, starving. Gonad development is presented as the percent of females in GS1 to 4 and D at the start and end of a $5 \mathrm{~d}$ incubation experiment. For each GS analysis, 20 to 25 females were examined tions, the gonad maturity of the females decreased and their egg production remained low.

On the following sampling dates (March 18, April 1 and 11), most females were mature at capture and egg production was greater than 20 eggs female ${ }^{-1}$ $\mathrm{d}^{-1}$ (see Fig. 2). When females, caught on March 18, were fed for $5 \mathrm{~d}$, they continued reproducing actively as indicated by egg production rates varying between 10 and 20 eggs female ${ }^{-1} \mathrm{~d}^{-1}$, and high proportions of mature females at the end of the experiments (Fig. 5). In starving females, egg production decreased within $24 \mathrm{~h}$ and did not exceed 2 eggs female ${ }^{-1} \mathrm{~d}^{-1}$ on Days 3 to 5 . In addition, gonad maturity decreased from approximately $80 \%$ GS4 to less than $40 \%$.

By April 16, the majority of the females in the Lurefjord carried degenerating oocytes, and GS4 comprised only $30 \%$ of females. Consequently, egg production rates were low. During feeding, females re-developed their gonads but only to GS3. The proportion of GS4 had not increased at the end of the experiment and egg production rates were still low, varying between 9 and 14 eggs female ${ }^{-1} \mathrm{~d}^{-1}$.

All experiments carried out from April 23 (Fig. 5) to May 28 started with females which had degenerated gonads (60 to $90 \%$ ) and had ceased egg production. Neither fed nor starving females re-developed their gonads and there was no egg production in either group. These females had obviously stopped feeding, as despite exposure to high algal concentrations, no faecal pellets were produced during the $5 \mathrm{~d}$ period.

\section{DISCUSSION}

Although the distribution of Calanus glacialis is usually restricted to Arctic water masses (Conover 1988), this species dominated the zooplankton community in the Lurefjord during our study. This fjord is relatively enclosed without much water exchange with the open ocean (see Bagøien et al. 2001). However, at the end of May, a single peak of mature females was found which points to advection. Visual predators such as fishes were lacking and the resulting low predation pressure on large copepods (Eiane et al. 1999) might be one reason why a population of $C$. glacialis has established there.

During our investigation in the Lurefjord, the reproductive activity of Calanus glacialis females was obviously uncoupled to the phytoplankton bloom. Egg production started at the beginning of March and peaked on March 28 before the beginning of the spring bloom; thereafter, it declined rapidly in parallel with the descent of the females to deeper waters, long before the end of the bloom. C. glacialis is 
Table 2. Calanus glacialis. Beginning of spawning (month) and maximum egg production rate $\left(\right.$ EPR $=$ eggs female $\left.\mathrm{e}^{-1} \mathrm{~d}^{-1}\right)$ at different locations

\begin{tabular}{|lcccl|}
\hline Location & Lat $\left({ }^{\circ} \mathrm{N}\right)$ & Month & EPR & \multicolumn{1}{c|}{ Source } \\
\hline Lurefjord & 60 & Mar & 36 & This study \\
Barents Sea & 77 & Mar/Apr & 46 & Hirche \& Kosobokova (2003) \\
White Sea & 65 & May & - & Kosobokova (1998) \\
East Greenland Shelf & 80 & May & 112 & Hirche \& Kwasniewski (1997) \\
Hudson Bay & 54 & Apr & 18 & Runge et al. (1991) \\
Baffin Bay & 77 & Apr & - & Ringuette et al. (2002) \\
Laptev Sea & 76 & Jul & 60 & Kosobokova \& Hirche (2001) \\
Disco Bay & 69 & Mar & 42 & Niehoff et al. (2002) \\
& & & & \\
\hline
\end{tabular}

apparently ready to spawn even early in the year, if food is present (Tourangeau \& Runge 1991), but also from lipid reserves (Hirche \& Kattner 1993). In the Lurefjord, the first mature females and egg production were observed on March 3, which is among the earliest records for $C$. glacialis (Table 2). The chl a concentration at that time was low. Unfortunately, we do not have samples to check for micro-zooplankton availability in spring. However, the experiments clearly showed that females were food limited, and neither cannibalism nor micro-zooplankton, if at all, supplied sufficient energy for high reproductive activity.

Maximum egg production rates were achieved even at low chl a concentrations, thus supporting recent observations of efficient utilisation of low food concentrations by Calanus glacialis from the Barents Sea by Hirche \& Kosobokova (2003). Maximum egg production rates were 36 eggs female $\mathrm{e}^{-1} \mathrm{~d}^{-1}$ in the field and in feeding experiments. These rates are lower than those reported previously from different parts of the Arctic (Table 2); however, females in the Lurefjord were much smaller than elsewhere.

The reproductive cycle of Calanus glacialis in the Lurefjord is completely different from what is known for C. finmarchicus and C. helgolandicus, the other Calanus species in this fjord (Bucklin et al. 2000). C. finmarchicus and C. helgolandicus females are dependent on food supply; hence, their reproductive period is timed more closely to the spring phytoplankton development with maximum gonad maturity and egg production rates during the bloom (e.g. Diel \& Tande 1992, Niehoff et al. 1999, Harris et al. 2000, Irigoien et al. 2000, Niehoff \& Hirche 2000).

Calanus glacialis is able to maintain high egg production rates over several months (Hirche \& Kwasniewski 1997, Hirche \& Kosobokova 2003). In the Lurefjord, spawning ceased despite increasing food concentrations due to the beginning of the spring bloom and females descended to lower depths from the surface layers. Gonads became depleted as in star- vation experiments, which agrees well with our observations that no faecal pellets were produced. Furthermore, feeding was not resumed when food was offered after the descent, indicating a deep physiological change such as dormancy. In earlier experiments, C. glacialis had resumed feeding quickly after starvation periods of up to $9 \mathrm{mo}$ in the laboratory (Hirche 1989). The descent and cessation of food uptake were obviously under the same control. The question is, what caused the abrupt descent and cessation of reproductive activity at a time when food was plentiful? From a comparison of gonad stages and vertical distribution of C. glacialis in the White Sea collected in different years, Kosobokova (1998) concluded that the key factor causing the termination of the spawning period of C. glacialis was the increase in temperature in the surface layer. When daily average temperatures near the surface reached $5^{\circ} \mathrm{C}$, females left the surface layers and stopped spawning. This fits well with our observations in the Lurefjord, where the reproductive period started at mean temperatures of ca. $4.90^{\circ} \mathrm{C}$ in the upper $50 \mathrm{~m}$ in the beginning of March. Between March 28 and April 11, stratification started in the surface layer (Eiane et al. 2002) and mean temperature increased to $5.65^{\circ} \mathrm{C}$ (Fig. 2). Stratification and/or increase in temperature apparently were sufficient to initiate the descent of the females to the cooler near-bottom waters and the arrest of their reproductive activity. Interestingly, with the temperature increase in the lowest water layer towards the end of our study period, females seemed to move upward into the cooler intermediate waters. Temperature seems to affect mainly adults and copepodite stage V. Younger stages remained in the warmer surface layer in the White Sea in June, when females had already descended to colder waters (Kosobokova 1998).

Obviously, the time window for reproduction of Calanus glacialis in the Lurefjord is very short. In its centres of distribution, the seasonally sea-ice covered Arctic seas, temperatures are below $0^{\circ} \mathrm{C}$ until the ice melt is completed, but then temperatures may increase rapidly. Climate change with decreasing sea-ice thickness and earlier ice melt, as observed for large parts of the Arctic (Johannessen et al. 2002), may reduce the reproductive period of $C$. glacialis considerably. In the case of the Lurefjord, it might even extinguish the population.

Factors initiating dormancy in copepods have so far mainly been studied in freshwater cyclopoid copepods (reviews in Dahms 1995, Williams-Howze 1997). In these copepods, there is strong evidence for the regu- 
lation by photoperiod, while temperature may only modify the effect of the photoperiod (e.g. Hairston et al. 1990). In addition, light was suggested to initiate dormancy in calanoid copepods (Miller et al. 1991). In contrast, the descent of Calanus glacialis females was closely coupled to temperature and took place between March in the Lurefjord (this study) and June in the White Sea (Kosobokova 1998), which makes an effect of photoperiod unlikely. Temperature may be a more appropriate cue than light, as in the Arctic, food availability is very variable in both time and space. For example, in polynyas, phytoplankton develops much earlier than outside polynyas (Hirche \& Kwasniewski 1997). Similar control mechanisms may act on dominant herbivorous species in upwelling systems such as Calanoides carinatus (Binet \& Smith de Saint Claire 1975). These species leave the surface waters, which become warmer towards the end of the upwelling season, and aestivate in deeper waters. In upwelling areas, there are only small seasonal variations in day length (Miller et al. 1991), and the upwelling seasons are very variable in both timing and duration, which makes light an unlikely trigger for descent.

Usually, dormancy includes quiescence and diapause. In quiescence, the organisms recover quickly when environmental conditions become favourable, while diapausing organisms have to pass a refractory phase before development continues. In our case, it is difficult to distinguish between quiescence and diapause, as in the deep water and in our incubations, temperature was not appropriate. In contrast, temperatures in the White Sea deeper waters are cold enough all year round, so that descended females could have recovered quickly. Nevertheless, gonads were resorbed there as well and females rested until gonad maturation started again in mid-February (Kosobokova 1999).

The adaptive significance of a period of dormancy in deeper waters is high in Arctic copepods. In Calanus glacialis, as in the other large Arctic copepod, $C$. hyperboreus, females are multiannual iteroparous; therefore, energy saving and protection of 'reproductive value' (sensu Fisher 1930) during overwintering is essential for resuming reproduction during the following spring. In the Arctic, predation pressure on the surface by birds (Weslawski et al. 1997) or epontic amphipods (Werner et al. 2002) is stronger than in deeper waters and, in addition, avoidance of competition for food with the copepodites and of cannibalism on earlier life stages may be important. In the Lurefjord, data from Eiane et al. (2002, their Table 3) suggest a significant contribution of females to egg and naupliar mortality; hence, the descent of postreproductive females may enhance the survival of the population.
Acknowledgements. We would like to thank Dag Asknes and the staff of the High Technology Centre Bergen as well as the captain and the crew of the RV 'Hans Brattstøm' for their support and for providing chlorophyll and temperature data. We also thank S. Duesterloh, who helped to carry out the sampling and the experiments. This work was supported by funding from the European Commission through the TASC project, Contract MAS3-CT-95-0039, and through a Large Scale Facility grant, Contract LSF4, ERGFMGECT950013.

\section{LITERATURE CITED}

Bagøien E (1999) Predatory impact of invertebrates and fish on overwintering Calanus. Dr. Sci thesis, Department of Biology, University of Oslo

Bagøien E, Kaartvedt S, Aksnes DL, Eiane K (2001) Vertical distribution and mortality of overwintering Calanus. Limnol Oceanogr 46:1494-1510

Binet D, Suisse de Sainte Claire E (1975) Le copepode planctonique Calanoides carinatus, repartition et cycle biologique au large de la Cote d'Ivoire. Cah ORSTOM Ser Océanogr 13:15-30

Bucklin A, Kaartvedt S, Guarnieri M, Goswami U (2000) Population genetics of drifting (Calanus spp.) and resident (Acartia clausi) plankton in Norwegian fjords. J Plankton Res 22:1237-1251

Campbell RG, Runge JA, Durbin EG (2001) Evidence for food limitation of Calanus finmarchicus production rates on the southern flank of Georges Bank during April 1997. DeepSea Res II 48:531-549

Conover RJ (1988) Comparative life histories in the genera Calanus and Neocalanus in high latitudes of the northern hemisphere. Hydrobiologia 167/168:127-142

Dahms HU (1995) Dormancy in copepoda-an overview. Hydrobiologia 306:199-211

Diel S, Tande K (1992) Does the spawning of Calanus finmarchicus in high latitudes follow a reproducible pattern? Mar Biol 113:21-31

Durbin EG, Garrahan PR, Casas MC (2000) Abundance and distribution of Calanus finmarchicus on the Georges Bank during 1995 and 1996. ICES J Mar Sci 57:1664-1685

Eiane K, Aksnes DL, Bagøien E, Kaartved S (1999) Fish or jellies - a question of visibility? Limnol Oceanogr 44: 1352-1357

Eiane K, Aksnes DL, Ohman MD, Martinussen MB (2002) Stage-specific mortality of Calanus spp. under different predation regimes. Limnol Oceanogr 43:636-645

Fisher RA (1930) The genetical theory of natural selection. Clarendon Press, Oxford

Gaard E (2000) Seasonal abundance and development of Calanus finmarchicus in relation to phytoplankton and hydrography on the Faroe Shelf. ICES J Mar Sci 57: 1605-1611

Gislason A, Astthorsson OS (1996) Seasonal development of Calanus finmarchicus along an inshore-offshore gradient southwest of Iceland. Ophelia 44:71-84

Grainger EH (1963) Zooplankton from the Arctic Ocean and adjacent Canadian waters. J Fish Res Board Can 22: $543-564$

Hairston NG, Dillon TA, De Stasio BT (1990) A field test for the cues of diapause in a freshwater copepod. Ecology 71 : $2218-2223$

Harris RP, Irigoien X, Head RN, Rey C, Hygum BH, Niehoff B, Meyer-Harms B, Carlotti F (2000) Feeding, growth and reproduction in the genus Calanus. ICES J Mar Sci 57: 1708-1726 
Hirche HJ (1989) Egg production of the Arctic copepod Calanus glacialis - laboratory experiments. Mar Biol 103: 311-318

Hirche HJ (1997) The life cycle of the copepod Calanus hyperboreus in the Greenland Sea. Mar Biol 128:607-618

Hirche HJ, Kattner G (1993) Egg production and lipid content of Calanus glacialis in spring: indication of a fooddependent and food-independent reproductive mode. Mar Biol 117:615-622

Hirche HJ, Kosobokova K (2003) Early reproduction and development of dominant calanoid copepods in the sea ice zone of the Barents Sea-need for a change of paradigms? Mar Biol 143:769-782

Hirche HJ, Kwasniewski S (1997) Distribution, reproduction and development of Calanus species in the Northeast Water in relation to environment conditions. J Mar Syst 10: 299-317

Hirche HJ, Mumm N (1992) Distribution of dominant copepods in the Arctic Ocean in summer. Deep-Sea Res 39: 485-505

Hirche HJ, Hagen W, Mumm N, Richter C (1994) The Northeast Water Polynya, Greenland Sea. III. Meso- and macrozooplankton distribution and production of dominant herbivorous copepods during summer. Polar Biol 14: 491-503

Hirche HJ, Brey T, Niehoff B (2001) A high frequency time series at weathership $M$, Norwegian Sea: population dynamics of Calanus finmarchicus. Mar Ecol Prog Ser 219:205-219

Hopkins TL (1969) Zooplankton standing crop in the Arctic Basin. Limnol Oceanogr 14:80-85

Irigoien X, Head R, Klenke U, Meyer-Harms B, Harbour D, Niehoff B, Hirche HJ, Harris R (1998) A high frequency time series at weathership M: feeding of adult female Calanus finmarchicus. Mar Ecol Prog Ser 172:127-137

Irigoien $\mathrm{X}$, Head RN, Harris RP, Cummings D, Harbour D, Meyer-Harms B (2000) Feeding selectivity and egg production of Calanus helgolandicus in the English Channel. Limnol Oceanogr 45:44-54

Jaschnov WA (1970) Distribution of Calanus species in the seas of the northern hemisphere. Int Rev Ges Hydrobiol 55:197-212

Johannessen OM, Bengtsson L, Miles MW, Kuzmina SI and 8 others (2002) Arctic climate change-observed and modeled temperature and sea ice variability. Technical Report No. 218, Nansen Environmental and Remote Sensing Center, Bergen, p 1-22

Kosobokova KN (1998) New data on the life cycle of Calanus glacialis in the White Sea (based on seasonal observations of its genital system development). Oceanology 38 : $347-355$

Kosobokova KN (1999) The reproductive cycle and life history of the Arctic copepod Calanus glacialis in the White Sea. Polar Biol 22:254-263

Editorial responsibility: Otto Kinne (Editor-in-Chief), Oldendorf/Luhe, Germany
Marshall SM, Orr AP (1955) The biology of a marine copepod Calanus finmarchicus Gunnerus. Oliver \& Boyd, Edinburgh, p 1-188

Miller CB, Cowles TJ, Wiebe PH, Copley NJ, Grigg H (1991) Phenology in Calanus finmarchicus; hypotheses about control mechanisms. Mar Ecol Prog Ser 72:79-91

Niehoff B (2000) The effect of starvation on the reproductive potential of Calanus finmarchicus. ICES J Mar Syst 57: 1764-1772

Niehoff B, Hirche HJ (1996) Oogenesis and gonad maturation in the copepod Calanus finmarchicus and the prediction of egg production from preserved samples. Polar Biol 16: $601-612$

Niehoff B, Hirche HJ (2000) The reproduction of Calanus finmarchicus in the Norwegian Sea in spring. Sarsia 85: $15-22$

Niehoff B, Klenke U, Hirche HJ, Irigoien X, Head R, Harris R (1999) A high frequency time series at Weathership $M$, Norwegian Sea, during the 1997 spring bloom: the reproductive biology of Calanus finmarchicus. Mar Ecol Prog Ser 176:81-92

Niehoff B, Madsen S, Nielsen TG, Hansen B (2002) Reproductive cycles of three Calanus species in Disko Bay, West Greenland. Mar Biol 140:567-576

Plourde S, Runge JA (1993) Reproduction of the planktonic copepod Calanus finmarchicus in the Lower St. Lawrence Estuary: relation to the cycle of phytoplankton production and evidence for a Calanus pump. Mar Ecol Prog Ser 102: $217-227$

Ringuette M, Fortier L, Fortier M, Runge J, Belanger S, Larouche P, Weslawski JM, Kwasniewski S (2002) Advanced recruitment and accelerated population development in Arctic calanoid copepods in the North Water. Deep-Sea Res II 22-23:5081-5099

Runge JA, Roff JC (2000) The measurement of growth and reproductive rates. In: Harris R, Wiebe P, Lenz J, Skjoldal HR, Huntley $M$ (eds) ICES zooplankton methodology manual. Academic Press, San Diego, CA, p 401-454

Smith SL, Schnack-Schiel SB (1990) Polar zooplankton. In: Smith WO (ed) Polar oceanography. Part B. Chemistry, biology, geology, Vol 2. Academic Press, New York, p 527-598

Tourangeau S, Runge JA (1991) Reproduction of Calanus glacialis under ice in spring in southeastern Hudson Bay, Canada. Mar Biol 108:227-233

Werner I, Auel H, Friedrich C (2002) Carnivorous feeding and respiration of the Arctic under-ice amphipod Gammarus wilkitzkii. Polar Biol 25:523-530

Weslawski M, Stempniewicz L, Mehlum F, Kwasniewski S (1999) Summer feeding strategy of the little auk (Alle alle) from Bjørnøya, Barents Sea. Polar Biol 21:129-134

Williams-Howze J (1997) Dormancy in the free-living Copepod orders Cyclopoida, Calanoida, and Harpacticoida. Oceanogr Mar Biol Annu Rev 35:257-321

Submitted: March 25, 2004; Accepted: September 2, 2004 Proofs received from author(s): December 22, 2004 